\title{
LETTER
}

\section{Anemia and blood transfusion and outcome on the intensive care unit}

\author{
Marcella CA Müller* and Nicole P Juffermans \\ See related research by Sakr et al., http://ccforum.com/content/14/3/R92
}

The observation of Sakr and colleagues that transfusion may be beneficial in certain subgroups of intensive care unit (ICU) patients [1] is interesting, since large observational studies demonstrate that transfusion is independently associated with an increased risk of death [2]. Also, a systematic review showed that the benefits of transfusion in the ICU do not outweigh the risks [3]. Sakr and colleagues ascribe their discrepant results to the fact that transfused blood was leukoreduced. Of the 17 randomized controlled trials on the association of nonleukoreduced blood with mortality, however, a benefit of leukoreduction was found only in cardiac surgery patients [4]. A metaanalysis confirmed that available evidence does not justify universal leukoreduction [5].
Given the increased risk of nosocomial infection, multiple organ failure and acute respiratory distress syndrome, an explanation of a beneficial effect from transfusion in anemic critically ill patients is tempting. We propose that the results of this study may be related to the indication of transfusion, this being active bleeding and not correction of anemia associated with critical illness. Hereby, transfusion may have prevented adverse events due to postoperative bleeding, explaining the survival benefit. The fact that $76 \%$ of patients were referred from the operating/recovery room and that the median length of ICU stay was only 1 day may support this hypothesis. Based on numerous reports on the association of transfusion with adverse outcome, a liberal transfusion strategy in critically ill anemic patients in the absence of acute bleeding should not be advocated.

\section{Anemia and blood transfusion: what do we really know?}

Yasser Sakr and Konrad Reinhart

We read with interest the comment by Müller and Juffermans. In our study, we did not attribute the possible beneficial effects of red cell transfusion only to leukoreduction [1]. The different case mix in our study and the possible change in practice and quality of care could have been other factors explaining our results. In addition, intensivists are now more aware of the meaning of various parameters that reflect tissue oxygenation and microvascular perfusion. These parameters are increasingly used in the ICU in addition to clinical evaluation to establish indications for blood transfusion.

Müller and Juffermans also misinterpreted our data somewhat, by assuming that the indication for blood transfusion was mostly active bleeding. The fact that $76 \%$

*Correspondence: m.c.muller@amc.uva.nl

Department of Intensive Care, Academic Medical Centre, University of Amsterdam, Meibergdreef 9, 1105 AZ Amsterdam, the Netherlands of patients were referred from the operating/recovery room is simply because our ICU is a surgical ICU, and the median ICU stay in transfused patients was 4 days and not 1 day. Around 58\% of our patients received only 1 or 2 units of blood and the number of transfused units was not associated with a higher risk of death in the multivariate analysis. Our previous observation from the Sepsis Occurrence in Acutely Ill Patients study in a mixed ICU population also does not support the active bleeding hypothesis as a single important player [6]. Generalizing the evidence derived from the literature without taking into consideration the specific case mix may not be justified. In surgical ICU patients, results from a large cohort like ours are hypothesis generating and may guide clinical practice pending the results of randomized control trials.

Abbreviations

ICU, intensive care unit.

Competing interests

The authors declare that they have no competing interests. 
Published: 25 August 2010

\section{References}

1. Sakr Y, Lobo S, Knuepfer S, Esser E, Bauer M, Settmacher U, Barz D, Reinhart K: Anemia and blood transfusion in a surgical intensive care unit. Crit Care 2010, 14:R92.

2. Vincent JL, Baron JF, Reinhart K, Gattinoni L, Thijs L, Webb A, Meier-Hellmann A, Nollet G, Peres-Bota D; ABC (Anemia and Blood Transfusion in Critical Care) Investigators: Anemia and blood transfusion in critically ill patients. JAMA 2002, 288:1499-1507.

3. Marik PE, Corwin HL: Efficacy of red blood cell transfusion in the critically ill: a systematic review of literature. Crit Care Med 2008, 36:2667-2674.

4. Vamvakas EC, Blajchman MA: Transfusion-related immunomodulation (TRIM): an update. Blood Rev 2007, 21:327-348
5. Vamvakas EC: White-blood-cell-containing allogeneic blood transfusion and postoperatieve infection or mortality: an updated meta-analysis. Vox Sang 2007, 92:224-232.

6. Vincent JL, Sakr Y, Sprung C, Harboe S, Damas P: Are blood transfusions associated with greater mortality rates? Results of the Sepsis Occurrence in Acutely III Patients study. Anesthesiology 2008, 108:31-39.

doi:10.1186/cc919

Cite this article as: Müller MCA, Juffermans NP: Anemia and blood transfusion and outcome on the intensive care unit. Critical Care 2010, $14: 438$ 